\title{
A CARTOGRaphy OF ANGRY INDIAN GodDESSES TOWARDS NOMADIC AFFECT
}

INDRANI MUKHERJEE

Jawaharlal Nehru University indrani.manshobhat@gmail.com

Received: 31-10-2019

Accepted: 17-12-2019

\begin{abstract}
(c) (1)
Abstract

This paper attempts to draw a cartography of becoming Angry Indian Goddesses as transnational nomadism towards an embodied and material rethinking of women's friendships from outside the constraints of systemic binaries. The friends are all professional women who are globally wired, whose thinking minds and non-docile bodies detach themselves from any normative modes of belonging in their respective personal and professional realms. They map a post-humanist spatiality of rhizomic linkages with other animate and non-animate entities, throwing up a new ethics of nomadic affect and responsibility. The film begins with a panoramic gaze of the Goan landscape, overlapped with flash images of Hindu goddesses and their animal escorts framed within a power packed song "Kattey", which intersects Bhanwari Devi's powerful folk composition of Meera Bai's 15th century mystic tradition with Haard Kaur's rap. The crossing of the song and the violent events of rejection that the women face, unbridle a becoming angry goddesses through a pastiche of the anxious goddesses and women sited on an axis of re/de-valorised difference. Goa becomes a potential third space entangled with all of the above, as it dwells on the contemplative scope of this cartography as redemptive and suggests a re-humanization of schizophrenic splintered objects through love and affect.
\end{abstract}

KEYWORDS: women friends, embodied, interstitial space, hybrid, non-Human, becoming, nomad.

\section{RESUMEN Una cartografia de Angry Indian Goddesses: Hacia un afecto nómada}

Este artículo se propone trazar una cartografía del "becoming" (proceso) en el film Angry Indian Goddesses como nomadismo transnacional, con el fin de reconsiderar la amistad femenina desde una perspectiva física y material que va más allá de los sistemas binarios. Todas las amigas son profesionales conectadas a nivel global, cuyas mentes pensantes y cuerpos insumisos se alejan de cualquier modo normativo de pertenencia en sus ámbitos personales y profesionales. Estas amigas cartografían una espacialidad post-humanista de conexiones rizomáticas con otras entidades animadas e inanimadas, proponiendo una nueva ética del afecto nómada y la responsabilidad. La película empieza con una mirada panorámica del paisaje de Goa al que se superponen rápidas imágenes de diosas hindúes con sus mascotas animales, mientras que la banda sonora consiste en la poderosa pieza de rap "Kattey", de Haard Kaur, en intersección con la enérgica versión folk que Bhanwari Devi hace de la tradición mística del siglo XV de Mirabai. La combinación de la música y la violencia del rechazo que sufren las mujeres pone en evidencia un becoming angry goddesses mediante un pastiche de las diosas enfadadas y las mujeres que habitan un eje de diferencia re/desvalorizada. Goa se convierte en un potencial tercer espacio imbricado con todo lo anterior, pues aparece como elemento redentor dentro del marco contemplativo de esta cartografía, y propone una re-humanización de objetos fragmentados y esquizofrénicos mediante el amor y el afecto.

PAlABRAS ClAVE: amigas, corporalidad, espacio intersticial, híbrido, no-humano, proceso, nómada 


\section{Introduction: Drawing a cartography}

Transnational nomadic movements through global trajectories explored in contemporary narratives draw new maps of transitional spaces to highlight a nomadic ontology of spatiality, which are problematically gendered-queer, embodied-disembodied and dialogicplurivocal, that is to say, hybrid, interstitial and intersectional. They reminisce rhizomic moves (sideways/lateral/simultaneous/random) of transiting bodies which grope through inhospitable zones such as deserts and plateaus or the sea and sand, or jungles and swamps, or super modern but unknown ones such as airports, immigration offices, urban ghettos, borderlands, embodied 'polyglotisms', the psychiatric clinic, the hotel, etcetera. These stories narrate their struggles in order to survive, desire, fetishize, escape, and die or simply to be thought about. Tools used for mapping such moves of nomadic subjects in terms of their materialistic situatedness, which may be embedded and embodied socio-politically or culturally, in the age and space of global hybridity are the cartographies that this paper will attempt to map. They explore terrains of becoming gendered rather than of the gender-effect, which negotiate through weird possibilities of a new aesthetics of non-unitary nomadism, based on contingency of history, arbitrariness of language, affective desires, and unstable epistemologies, thus dispensing with any geophysical security/stability of borders. They call on gestating readings, which will labour through non-conformity with prescribed and patronising ways of thinking to birth new grounds of a disturbing and distinct epistemological order. The post-partum troubles, however, will continue as the nomadic wanderings continue. Negotiating 'gendered' nomadism entails 'becoming' an oasis of empathy and compassion through transgressions, translations, translocations and transculturation. This paper dwells on the film Angry Indian Goddesses, located in Goa, to map its narrative through the turbulent weathers of global transitory spaces, real or intellectual turfs of interstitial/rhizomic nomadic epistemologies as political resistance to the exclusionary practices of crony-capitalism in a violently wired world. The issue of "cartography" takes it (this cartography) away from humans as subject to the post-human, highlighting the linkages of the non-Human as well, to include animals, vehicles, a gun and the Goan space. The narrative dwells on the contemplative scope of this cartography as redemptive and suggests a re-humanization of schizophrenic splintered objects through love and affect. 
Films based on women's friendship in India are a very recent phenomena and almost each one of them have sparked most difficult public debates provoking riot-like situations, police action and directorial compromise. This was the case with Deepa Mehta's films Fire (1998), Water (2007), Nagesh Kukunoor's Dor (2006) Leena Yadav's Parched (2016) and Alankita Srivasta's Lipstick under my Burkha' (2017), more recently. What was unique in all of them was the fact that the women protagonists were deeply entangled with caste, community and religious webs of identities of a collectivity concentrated into a monolithic male nationalistic narrative. The stories in these films were of girls and women friends struggling to shake off this repressive monolith to try to articulate and work with multiple identities of gender and feminine agency in order to reject and yet survive the hegemonic entanglements on their own terms. Indian feminist theories are cognisant of these situations where women's bodies are objectified and guarded for their sexuality and for serving as border keepers of family/community and religious identities as they are the makers of homes and hearths, the ones who birth children and socialize them to communitarian etiquettes.

In this sense, Pan Nalin's Angry Indian Goddesses (referred to as $A I G$ from now on) is a very different female friendship film. The film won audience awards in the film festivals of Toronto and Rome and has received some interesting critical acclaim in the west. It rethinks women's friendship from outside the constraints of systemic binaries to propose instead a multiplicity and heterogeneity of rhizomic linkages without hierarchies, susceptible to multiple points of entry into a monologic Oedipal set-up, thus dispensing with any fixity of borders or givens as defining characteristics. They are all professional women, (except for Pam or Pamela Jaiswal who aspires to become one), whose thinking minds and non-docile bodies become obstructions for them in their respective personal and professional choices. Thus, Frida is a photographer who refuses to shoot a fairness creams advertisement because, for her employers, only 'fairness' is important and they don't recognize or value her skills with the camera as an artist; Madhurita or Mad can't be appreciated as a night-club singer, because she gets abused by the lewd remarks about her body by some guys in the club; Pam is a trophy wife given her beauty and her intelligence yet she gets abused in a gym, precisely on account of her body; Suranjana or $\mathrm{Su}$ is an aggressive corporate executive who draws a lot of attention from her colleagues because of her ruthless and the near-masculine bearing of her body and mind; Nargis is an activist and the most radical of them all as she is gay and a Muslim. Joanna or Jo is a 
British-Indian cousin of Frida and is an aspiring Bollywood actress, who also gets abused for refusing to fit in into Bollywood narratives of damsel-in-distress roles. Friendship becomes a line of flight ${ }^{1}$ from sedentary universal ways of belonging to reckon with new possibilities of nomadic deterritorializations. They are the angry ones who throw up their jobs as they defy the order of things, unleashing the driving impulse of their pent-up energies to lines of flight to any kind of a 'beyond'. The film begins with these events of claustrophobic misogyny, overlapped with images of goddesses and their animal escorts of the tiger, the swan and the owl framed with a power-packed song "Kattey". The song has used cuts from a wide range of genres such as folk, hip hop, rock, cheesy pop. The powerful voice is of Bhanwari Devi, singing a Rajasthani folk composition by Meera Bai from the $15^{\text {th }}$ century mystic tradition, overlapped with Haard Kaur's rap, whose lyrics cover the '84 riots, her abandonment and orphanhood thereafter, accompanied by Ram Sampath's orchestra. ${ }^{2}$ Cut-and-paste images, sounds and bodies thus juxtaposed, anticipate the instability of things to come. That is how the entire film runs, with longer cuts eventually comprising flashbacks, digressions, metanarratives and even visual stills. Images, sounds and bodies perform an assemblage to tell a story, while also complicating the narrative.

\section{Transnational nomadism}

Nomadism negotiates advanced capitalism and the consequent mobility that it induces; it's about schizophrenic subjects and cartographies which splinter over and over again. Rosi Braidotti explicates nomadism in this way: "The figuration of the nomad renders an image of the subject in terms of a non-unitary and multi-layered vision, as a dynamic and changing entity." (Braidotti, 2011: 5). ${ }^{3}$ She argues how it is important to think differently through different points of reference and proposes that nomadism breaks "the dualistic conceptual constraints and perversely monological mental habits of phallocentric thought". (Braidotti, 2011: 22). Though Braidotti identifies displaced immigrants moving along finance-scapes and power dispensations, multicultural subjects serving labour requirements, as a potential people

\footnotetext{
${ }^{1}$ A Deleuzean concept implying an escape trajectory to transcend the immediate real towards the virtual. It implicates change in positionality in a liminal spatiality.

${ }^{2}$ It is possible to hear the rendition of the folk song here in English translation, though without the version actually presented in the film, which is without the rap. https://www.youtube.com/watch? $\mathrm{v}=\mathrm{K} 7 \mathrm{U} 3 \mathrm{oBm} 8 \mathrm{yWE}$ )

${ }^{3}$ A figuration she explains "is a politically informed image of thought that evokes or expresses an alternative vision of subjectivity". (Bradiotti, 2011: 22)
} 
becoming nomad, this paper attempts to read $A I G$ through the spectacles of non-Oedipal feminist nomadism as a narrative of transiting spaces, lives and identities. Nomads here move against the global tides, and Goa becomes that anti-Oedipal space which seems like another world. Thus, nomadism, in this story, maps movements away from three mega cities, Delhi, Mumbai and London to a transitory Goa, though the mega cities prevail in the backdrop. It is significant that Goa itself is the region which most reminisce the European legacy for centuries, while it is also lush with very unique local narratives. Goa is also an international tourist destination given its fantastic beaches, palm trees and local hospitality. At the same time, given the backdrop of these women friends' transitory nature, both as subjects and objects of the world they have provisionally left behind, this very world of global megacities constantly linger in the narrative.

The women nomads in the movie are shown as globally-wired subjects, working with international brands in the corporate sector; any issues with caste-community-religion are ironed out into near invisibility, to their advantage in terms of agency and freedom. This situation of nomadism may also be understood through the concept of 'liquid possession' of global nomads. ${ }^{4}$ Bardhi et al argue that global nomads see possessions as obstructions on the global tracks traversed during trans-geographical movements. A nomadic perspective challenges our existing views of possessions as central to consumer identity. It is significant, in this context that the women friends in Pan Nalin's story have left their jobs behind, or, as in the case of $\mathrm{Su}$, eventually give up a multi-million rupees project. They are not like migrants or expatriates who long for a home and relationships they left behind. Global nomads are liberated from conventional (patriarchal) emotional, social, and physical obligations. Friendship becomes this unique zone of breaking out of the spatialization imposed by conventional givenness of social belonging. Their mutual relationship of sisterhood and friendship falls outside any codes of patriarchal order, as in their relationship with the Goan space. Braidotti dwells on bell hooks' idea of "yearning” to address matters of empathy and compassion across race, class and sexual orientation as a conscious affective and political sensibility; nomadism in the same spirit becomes a transnational epistemological and political imperative towards comparable ends. (Braidotti, 2011: 22). Nomadism thus constitutes its content, its critical thinking and its spatiality.

\footnotetext{
${ }^{4}$ For more on this, see Fleura Bardhi et al.
} 
Going back to the film, while the female archetypes carry with them the burden of their bodies and their homes to preserve purity, here we find that they transgress all such borders as they don't submit to the prescribed orders. They reject any pure space of belonging and instead allow moves towards the impure, the contaminated, which lacks the traditional attributes of a home/nationality. The Goa beaches expose a multi-layered spatiality of event-potentialities lurking amidst international tourism, a hung-over colonial legacy, a secular pluriversalism, oddly 'gendered' bodies and policed assemblages. Between these spatialities, 'other' nonbodies of animate and non-animate "things" contaminate every de/re-territorialization so that nomadic wanderings through these spaces map another transnational decoloniality, negotiating a Third Space. ${ }^{5}$ While this third space 'locates' intersectional identities (global and local women of color, an indo-British white one as well as a local domestic help) as socio-politically queer, Jasbir Puar critiques intersectionality itself as problematic with further queering through the posthuman materialist theories of Donna Haraway's cyborg and Karen Barad's understanding of 'entanglements', among many others. This brings to the fore how the body is not only confined to the skin, as it is an assemblage. Jasbir Puar highlights this in the following manner, fantastically:

For the current purposes, assemblages are interesting because they de-privilege the human body as a discrete organic thing. As Haraway notes, the body does not end at the skin. We leave traces of our DNA everywhere we go, we live with other bodies within us, microbes and bacteria, we are enmeshed in forces, affects, energies, we are composites of information. Assemblages do not privilege bodies as human, nor as residing within a human/animal binary. Along with a de-exceptionalizing of human bodies, multiple forms of matter can be bodiesbodies of water, cities, institutions, and so on. Matter is an actor. (Puar, 2012: 57). ${ }^{6}$

Becoming nomad, in this sense would be about reconciling with the borderless and unstable limits of any bodies. Nomadism gestates another way of thinking against sluggish phallogocentric monologue towards feminist disdain and disloyalty. The film intersects with an urban space which hangs on like a ghost in the Goan landscape throughout the narrative, articulated through the altering eye of the camera. It traces bodies and spaces as mutually contained or contested so that it supplements the main story-telling. The visual "line of flight" thickens the plot and adds depth in unique ways as it articulates meaningful emotions and

\footnotetext{
${ }^{5}$ Third space as in Homi K. Bhabha's theorization of hybrid spaces or Edward Soja's of lived spaces. They become embodied spatiality in their continuous struggles and contestation of problematic belongings.

${ }^{6}$ Jasbir Puar has often referred to/ctitiqued the intersectional subjectivities of minorities such as Sikhs, Disabled and Terrorists from posthumanist ethos of overlapping textualities of humans, cyborgs and non-humans.
} 
silences. Frida, Mad, Pam, Jo, Su and her child Maya, Nargis and even Laxmi, each one of them have their unique moments of intense silence embodied with lived spatiality. Thus were the examples of Frida's announcement of her gay marriage through her body moves from a closet, Mad's withdrawal into her own shell when she reflects on her music dreams, Pam's secret realization of the futility of her marriage, Su's facing up to Nargis' presence, her child's articulation of her solitude through her hidden graffiti art and Nargis' response when Frida announced their gay wedding, all partake of the experiences of sharing and responsible ethics of friendship. Jo's and Laxmi's affective moments became the most sensitive parts of the story telling in this sense in more ways than can be imagined. The transnational as the global entangled with the local are materially visible throughout the narrative.

\section{Post-humanist spatiality of rhizomic linkages}

The transnational as global entanglement takes us through another plateau which networks through multiple cultures of the traditional, the post-modern and the modern, a dominant group, a citizens group, international tourists and a minority church-going one. Between these spatialities, 'other' non-bodies of animate and non-animate "things" (such as a car, a gun, a camera, a bull) contaminate every rhizomic de-territorialization and reterritorialization so that nomadic wanderings through transitory spaces map an-other transnational post-coloniality (a third postcoloniality a la Soja's Third Space, perhaps?)! Navigating through these interspatial cracks of semiotic performatives enables another way of thinking and doing critical thinking, without the contradictions of binaries with fixed geopolitical boundaries. Transnationalism gestates a 'rhizomic' thinking which reinstates the scope of retelling and theorizing from outside coloniality of power, rendering exposed glocal cultures of misogynistic violence as event-potentialities hidden under heterotopias of normative paradigms of postcolonial law and orderly societies.

While the desert is an ideal space for nomad thinking ${ }^{7}, A I G$ re-locates on the Goan beaches - partly sandy like the desert - and the rest, the sea, equally vast, abundantly lonesome and unstable. Thereafter, the narrative explores how the lives of these girls were interwoven in

\footnotetext{
${ }^{7}$ Deleuze and Guattari allude to the desert and the steppe as smooth spaces of the nomad, a space which stands in opposition to the striated space of the state, which is characterized by a form of free flowing occupation ( the nomad creates territory by 'distributing himself in open space') which over codes the forces of institutionalizations. Smooth space, the desert and the steppe, a space free from codifications which determine behavior is a metaphorical allusion to types of occupation which resist the political restrictions of the Foucauldian panopticon.
} 
strange ways, rhizomic deterritorializations, moving and shaking up their real or imagined selves as nomads in a pack, ${ }^{8}$ sojourning through the wilderness of a hitherto unknown world. Friendship becomes the sole premise (the red jeep can be seen as a metaphor) which carries them through this borderless nomad space. There is no room for the entry of any male, both literally and metaphorically; just as the bull intruding into Frida's house, Mad's boyfriend, who suddenly appears most unexpectedly, is also shown the door. The five Hindi speaking north Indian boys who show up when their jeep breaks down are violently defied and confronted as they make lecherous advances using a very base kind of language. Yet this man-less space in the friendship vehicle is a heixix (event potential) of a shipwreck that seems to loom large over them. The serene and calm waters of Goa's beauty heightens the pleasures of raw feminine friendship, but also evokes an eerie sensation, a premonition of things to come. None of the invitees know the reason for the invitation but they come anyway. As the girls push Frida to reveal why they had been invited and as she does reveal that it was for her wedding, there is lot of excitement. Then, when she tells them that it was a gay wedding, first there is disbelief and Pam faints with shock; eventually it sinks in and there is cheering again. But the situation is sombre again as Frida reveals that her father wouldn't be there for the wedding. The most sacred of the male, that is the father, within a patriarchal set up, also exits the nomadic space of events. ${ }^{9}$ Yet when they sing wedding songs, the father figure of 'babul', whose home the bride will leave, lingers on in their minds. The deep entanglements of the girls with the father figure can't be shed. The frequent barging in of the bull in Frida's house is a symbolic performative in this sense. It is a funny scene, destabilizing the 'becoming women' space-time every time.

Borders are not given, rather they are in a continuous flux of becoming and unbecoming. They are desired, designed and processed to produce unstable 'other' geographies. The pack of women in Goa draw a very significant border, which keeps out every male who treads their paths. In all the other films on female friendship mentioned earlier, such spaces are only possible inside domesticated ones, if at all, with the only exception of Parched. Yet, while in Parched we map a cartography which deterritorializes centrifugally into exile

\footnotetext{
${ }^{8}$ Pack is about a multiplicity of becomings in the production of assemblages that work to resist the normalisation of present geo-spatiality. See "1914: One or Several Wolves" in Deleuze and Guattari 26- 38.

${ }^{9}$ Since Frida lost her mother, it was her relationship with her father that gave her any sense of belonging in this world until now. The father therefore is sacred; however now she has entered nomad space where she is alone.
} 
and uncertain horizons, in this film, the cartography is ambiguous as it becomes an assemblage. Frida's ancestral house in Goa stretches its borders outside onto the Goan beaches. There are no men who are allowed in this space, though they sometimes barge in. The red jeep, in this sense is metaphoric as it seems to be the omnipresent narrator, even when it may not be visible on the screen. The moves of the pack in this film are multidirectional as they negotiate misogyny at the local level and also take cognisance of global situations drawn from international tourism and cosmopolitanism. It is for this reason that gender overflows into another territory, appropriating it, undoing it, moving ahead or staying put, throwing away any coded grammaticality. Pam's dysfunctional marriage performs moves which bring to the fore many hidden layers of an Indian arranged marriage, patriarchy, familial insecurities, nonperforming male sexuality, female surrender but intelligent doubts and energies that finally enables a call for divorce and an aspirational drive for agency, autonomy and self-assertion. The other heterosexual couple, Mad and her successful guitarist boyfriend, is also a problematic narrative, from outside any patriarchal dominant grammar, but is not explored much as Mad rejects him almost as soon as he enters Frida's house. The Dalit maid servants, Laxmi and her old aunt also participate in this confluence of feminine energies.

They are 'exiled' nomadic subjects, as they push themselves through some real hard facts of their lives to take stock of their wild and transitory status, of setting up tent or winding it up, breaking away from any oedipal plot of a 'monologic' (as opposed to dialogic) patriarchy or humanistic design. Suddenly they find themselves 'outside', sitting on the edge, beyond any belonging or desire of belonging. They move like a pack through nomad space and look formidable. A non-communicative mother-daughter relationship ( $\mathrm{Su}$ and her baby daughter, Maya) gets transformed as the baby becomes a member of the pack and is indulged by all. Their newly-felt nomadism in the hybrid spaces of the Goan beaches defy sedentary, universalized identities appertaining to the home and hearth. Each one of these relationships destabilize the patriarchal order in terms of problematizing heterosexuality as a given normativity. The queering of boundaries gives a big shake up to this narrative, just as it also anticipates the queering of spatiality of the global. ${ }^{10}$

\footnotetext{
${ }^{10}$ As in the song 'Kattey', where there is an overlap of images of Hindu goddesses with those of the girl friends in angry postures. On another occasion the same song is replayed in the middle of the movie but this time while on a jeep ride in Goa. The Goan landscape acquires the personality of a promising host with her unique cosmopolitan 'culture'.
} 
However Su and Nargis are two alpha females in the pack who are terrible enemies because Nargis is leading a protest movement of tribal peoples against Su's multinational office which is trying to acquire land for bauxite mining. The firm had already received large sums of money for this purpose from an international corporate giant. So when they meet most unpredictably, as Nargis arrives as a late entrant in the film, there is lot of bad air between them. Frida tries to pacify them and can't really change the situation very much, except that $\mathrm{Su}$ agrees to stay back for the wedding to walk the bride up the church aisle. Eventually Su decides to let go off the land acquisition project of the corporate sector, as a wedding gift to Frida and Nargis. A direct encounter between the global force and the local one gets transformed through the bonding of women's friendship and love. The complete de/re-territorialization of the material and the affective become a significant force to reckon with in terms of how it is articulated. As incredible as these events may appear, this film affirms that affect and desire have a kind of anti-essentialist event-potential energy, linked to bodily materialism. Thus Braidotti says:

\begin{abstract}
Moreover the political economy of global capitalism consists in multiplying and distributing differences for the sake of profit. It produces ever-shifting waves of genderisation and sexualisation, racialisation and naturalisation of multiple 'others'. It has thus effectively disrupted the traditional dialectical relationship between the empirical referents of Otherness women, natives and animal or earth others - and the processes of discursive formation of genderisation/racialisation/naturalisation. Once this dialectical bond is unhinged, advanced capitalism looks like a system that promotes feminism without women, racism without races, natural laws without nature, reproduction without sex, sexuality without genders, multiculturalism without ending racism, economic growth without development, and cash flow without money. Late capitalism also produces fat-free ice creams and alcohol-free beer next to genetically modified health food, companion species alongside computer viruses, new animal and human immunity breakdowns and deficiencies, and the increased longevity of these who inhabit the advanced world. Welcome to capitalism as schizophrenia! (Braidotti, 2011: 27). ${ }^{11}$
\end{abstract}

It's precisely these situations of a schizophrenic capitalistic set-up from which the girls run away. Their professional lives opened them up to genderisation/racialisation/naturalisation as they were cast into stereotypes of fairness cream, white body, western or Bollywood music, fertility clinic, smoking and drinking women and heterosexual normativity. Friendship becomes a new ethics of combining self-interests for an enlarged sense of community and non-

\footnotetext{
${ }^{11}$ See Rosi Braidotti. "Affirming the Affirmative: On Nomadic Affectivity" to understand the ethics of nomadic affect. Here she argues how affect and passion are ontological to Deleuze and Guattarri's philosophical dispositions.
} 
Oedepal belongingness. Such combinations also include the Goan space with its fauna and flora, its vast expanse of sea and sand. Su says so to Frida as she contemplates and inhales all of this. She is overwhelmed by her new friendship with Frida's friends, whom she 'eulogizes' as being crazy and exceptional as she negotiates this new ethics of nomadic belonging. It is significant to once again note here the song "Kattey", which remixes Bhanwari Devi's old folk composition of a 15 th century mystic poet with a twentieth century Haard Kaur rap. Meera Bai's sense of abandonment by the gods and her subsequent despair entangles with Kaur's lyrics on the ' 84 riots, her abandonment and near orphan-hood thereafter, her hopelessness and her empowerment through music; a rhizomic nomadism is invoked in the accompaniment of Ram Sampath's orchestra. It becomes a hybrid sound track, an assemblage, which articulates the nomadic ethics of multiple belonging through embodied lyrics of violent memories. It works like a poetic refrain every time that it plays, first in the beginning and then in the middle of the film. ${ }^{12}$

\section{Embodied material thinking}

The rhizomic assemblage moves in the form of a pack, mapping their cartographies without following any universal tracks. The pack moves towards embedded and embodied nomadism to mark transgressive traces against the discursive and material limitations of normative ontologies. It traverses the spatiality of Goa, reinventing it, as their own selves are also reinvented, to discover that the terrains traversed are not smooth but, rather, striated. Goa becomes a mirror which enables them to see their 'I' as an-other, sensitised to a kind of gendered consciousness they had never felt before. An assemblage of embodied spatiality and spatialized bodies contaminate, swivel, transgress and trash each other as they constantly destabilize, delegitimize and deform any imminence. The camera articulates this through some long shots as it sweeps through the embodied spatiality of Goa, especially in the evening, when dim contours of silhouettes of bodies against a blue grey haze of the waters and the skies seem to be in a dialogic relationship of embrace and compassion. Bodies, beaches, sea and sky and, eventually, even the bull, enter into this picture-perfect mode of storytelling.

However, women's nomadic bodies loitering through nomad space are always a threat to the governmentality question as compared to those of respectable conforming ones moving

\footnotetext{
${ }^{12}$ For more on this, see: Budhatya Chatttopadhyay, "Reconstructing Atmospheres: Ambient Sound in Film and Media Production".
} 
through spaces subject to surveillance. ${ }^{13}$ Panopticism finally catches up with nomadism in global spaces. Braidotti refers to 'erring', which, in the context of our movie, could compare with Phadke's 'loitering': “connoting the violation of norms as well as the activity of wandering - as a prompt to explore the critical potentials and risks of embracing error, randomness, failure, and non-teleological temporalities, and to do so across different disciplines and discourses." 14 Jo Ann, in the film, breaks away from the pack over a trivial matter of her British accent, a dangerous linguistic stuttering, so that the pack loses control and burdens itself into unprovoked disfluencies of unknown territories.

Goa eventually becomes a site for the gang-rape of Jo and of revenge murder by two of her women friends, Su and Mad. Generally rape is linked to the ritual of breaking into the woman's body as a racial, national or ethnic boundary. It is also an act of maintaining the 'purity' of home. Here, in this film, however, rape (gang rape, rather) is an act of revenge by a bunch of non-Goan Hindi-speaking guys with whom they earlier had a confrontation. It is clearly a case where at least one woman of the 'pack' is punished for loitering through the public space, alone and at night. In this context, nomadism as a 'reading', becomes problematic, either as an intellectual exercise or as a real feminist practice. There is a need to rethink an alternative strategy towards a political ethics of responsibility rather than political correctness. Nomadism could be understood in the way the story unfolds thereafter. The Goan beach becomes this rhizomic entanglement which ruptures any ontological securities of borders. There is only one border, that of a pack of females who carry their tents on their back and camp where they go. Su and Mad kill the five rapists in a fit of rage though the others try to stop them. After finding the body of Jo, all the girlfriends face the state machinery of law and order very boldly. Nobody is thinking of any 'home' any more nor of any 'place' with any fixity. The state police interrogations however try to push them towards 'placing them where they belong', ${ }^{15}$ but really can't cope with their defiant but quiet and controlled outbursts, surrounded mostly by silence. The girls who are sparsely dressed for a beach party, partly drunk and hysterical, become so

\footnotetext{
${ }^{13}$ In order to understand this situation, see Shilpa Phadke's book on embodied loitering and risk-taking through public space.

14 From the pamphlet of "Errans Lecture Series 2014-15" of the Berlin Institute for Cultural Inquiry at https://www.ici-berlin.org/series/errans-lecture-series-2014-15/). The pamphlet is a brief synopsis of a video lecture by Rosi Bradiotti.

${ }^{15}$ Incidentally, many convicted of rape have responded in the same way. They have never felt shame or remorse as they have said that the victim had to be shown her place. This was captured in the film Pink, where the accused admitted during the trial that he had wanted to show her where she belonged.
} 
thrown out of any imagined 'pure' space that it is not hard for them to reterritorialize back into a 'pack' of female nomad subjects. They reject any pure place of belonging and rather allow moves towards the impure, the contaminated 'non-space', which lack the traditional attributes of a home/nationality. ${ }^{16}$

Next day, when the church meeting becomes a mourning event, instead of a wedding, the pack is ready with all the rituals of mourning. The church hall is full and awaiting the commencement of a special mass. Each one of the friends of the pack delivers a sentimental speech, remembering Jo. But the ceremony is interrupted by the appearance of the police who announce that the murderer of five boys come out and surrender to the police. Gang rape is very significant in this manner of our reading the film as it pushes them back to the 'striated' spaces of the city and its order. Nomadism is scuttled and they are pushed back into the postcolonial spatiality as they now have to negotiate with the state and law. The oddity of the encounter of these girls with the local police is a case in point. They are judged on account of the clothes they are wearing, for having been drinking and smoking and finally for being out so late. Eventually they also have to face up to the issue of gay marriage. A cliché theme, as in the scene where they confront the police, finds a new de-clothing here.

Nomadism comprises mobility through post-human global-scapes involving moves which are embedded and embodied deterritorializations. Unlike the anarchist or the bohemian rag picker who purposefully avoids the world, the nomad encounters the world through a different and unique kind of ethics and responsibility. Such ethics involves taking a stance against dominant narratives or any moral universalism such as patriarchy, heterosexual normativity or monism. It is also about shaking off the given-ness of language and/or representation, of traditional narratives of causality or simply of trivialization of non-Oedepal and queer relationalities. This paper's attempt to read the film $A I G$ from perspectives of nomadism perhaps begs the question of how it can be justified given that the story is too farfetched and improbable, especially the last scene of the movie where there is public mourning and comradery in sharing the responsibility for murder. This has not been well received by Indian film critics. However, from the perceptions and perspectives of Braidotti's

\footnotetext{
${ }^{16}$ Interestingly, in many of the friendship friends mentioned earlier on in the paper, rape happens indoors as marital rape as in Fire, Lipstick under my Burkha and Parched. In Water, the rape of a child widow by a patriarch is partially redeemed by her surrender to the Father of the Nation. The rape of the adult widow however, drives her to suicide. For all the women in all these films, the 'outside' as an unknown space becomes emancipatory.
} 
'Nomadic Feminism', the question of feminism should not be about specifically feminine assemblages, rather about multiple ones in their rhizomic 'becoming' rather than in terms of production. ${ }^{17}$ Later she argues how this would "entail the embodiment of mind as much as the 'embrainment of matter'. There is only one substance: an intelligent flesh-mind-matter compound". (Braidotti, 2006:352). Embedded and embodied deterritorializations implicate sexuality, affectivity, empathy and desire as integral to an ethics of a non-unitary subject or a nomad. One has to think global but act local. (Braidotti, 2006:354). The most controversial parts of film have to be appreciated in this sense. In times when vigilante justice through mob violence has become the new norm, why can't vigilante justice by human emotions and responsibility also become a complex non-unitary nomadic becoming of a nomadic herd? Nomadism is that enabling becoming other in its relationality to one's ethical connections with all matter and non-matter. The last scene of the movie is that moment. It is significant that Goa also becomes a hybrid non-unitary spatiality, facing the west with potential transitions through different colonial locations and cultures.

\section{WORKS Cited}

BARDHI, F., \& BARDHI, G. M (2012, October). "Liquid Relationship to Possessions, Journal of Consumer Research, 510-529. https://doi.org/10.1086/664037 accessed on 23 October 2019.

BHABA, HOMI K (2017). Location of Culture. London \& New York: Routledge.

BRAIDOTTI, ROSI (1994). Nomadic Subjects: Embodiment and Sexual Difference in Contemporary Feminist Theory. New York: Columbia University Press.

BRAIDOTTI, ROSI (2006). "Affirming the Affective: On Nomadic Affectivity”, Rhizomes, Vol. 11-12. https://rosibraidotti.com/publications/affirming-the-affirmative-onnomadic-affectivity/ accessed on 15 August 2019.

BRAIDOTTI, ROSI (2011). Nomadic Theory: The Portable Rosi Bradiott, New York, Chichester, Sussex: Columbia University Press.

BRAIDOTTI, ROSI (2013). "Nomadic Ethics", Deleuze Studies, Vol. 7, No 3, 342-359. https://rosibraidotti.com/wp-content/uploads/2018/06/319.-Nomadic-Ethics.pdf accessed on 20.september accessed on 23 October 2019.

CHATTOPADHYA, BUDHADITYA (2017). "Reconstructing Atmospheres: Ambient Sound in Film and Media Production.", Communication and the Public, Vol. 2, . [?]

\footnotetext{
${ }^{17}$ Braidotti talks specifically of sexuality, though here there is no issue of this topic. Hence the word 'assemblages' is used to refer to embedded and embodied rhizomes. (Braidiotti, 2006:351).
} 
$\mathrm{N}^{\circ} 4,352-364$. https://doi.org/10.1177/2057047317742171 accessed on 30 September 2019.

FOUCAULT, MICHEL (1990). History of Sexuality. New York: Vintage.

HENN, Alexander (2000). "The Becoming of Goa. Space and Culture in the Emergence of a Multicultural Lifewold", Lusotopie, Vol. 7, 333-339.

HOOKS, BELL (2000). All about Love: New Visions. New York: Harper Collins.

JELACA, DIJANA (2018). "Alien Feminisms and Cinema's Posthuman Women", Signs:Journal of Women in Culture and Society, Vol. 43 Nº 2, 379-400.

MIGNOLO, WALTER (2009). "Epistemic Disobedience, Independent Thought and DeColonial Freedom", Theory, Culture and Society, Vol. 26 № 7-8, 1-23.

NALIN, PAN. (2015) Angry Indian Goddesses [Motion Picture]. Canada: Jungle Book.

PHADKE, SHILPA, SAMEERA KHAN AND SHILPA RANADE (2011). Why Loiter? Women and Risk on Mumbai Streets. New Delhi, New York,Toronto: Penguin.

PUAR, JASBIR (2012). “I Would Rather be a Cyborg”, philoSOPHIA: A Journal of Continental Feminism, Vol. 2, No 1, 49-66.

SOJA, EDWARD (1996). Third Space: Journeys to Los Angeles and other real and imagined spaces. Oxford: Blackwell.

SOJA, EDWARD (2011). Postmodern Geographies: The Reassertion of Space in Critical Social Theory. London \& New York: Verso.

IndRANi MukHeRJeE is Professor at the Centre of Spanish, Portuguese, Italian and Latin American Studies, JNU. Her publications include Comparative Literature, Cultural Studies and Pedagogy of Literature with respect to gender and spatiality. She has worked on two research projects on Comparative Gender Studies from India and Latin America. Her latest published books are Transcultural Negotiations of Gender: Studies in (Be)longing. Springer, 2016 and Gendered Ways of Transnational Unbelonging from a Comparative Literature Perspective, Cambridge Scholars Publication, 2019. 